JOANNA BARDZIŃSKA

AVA Arts Foundation

Madrid
Images

vol. XXIV/no. 33

Poznań 2018

ISSN 1731-45OX

\title{
Kieślowski in Spain: History, Reception and Inspiration
}

\begin{abstract}
Joanna Bardzińska, Kieślowski in Spain: History, Reception and Inspiration. "Images" vol. XXIV, no. 33, Poznań 2018. Adam Mickiewicz University Press. Pp. 117-127. ISSN 1731-450X. DOI 10.14746/i.2018.33.10.

The films of Krzysztof Kieślowski arrived in Spain comparatively late, and when they did so this was mainly due to the Film Festivals at San Sebastián and Valladolid, as well the efforts of independent producers like the brothers José María and Miguel Morales of Wanda Films. In 1988, A Short Film About Love was presented at the San Sebastián Festival, where it won the Special Prize and the FIPRESCI Prize, and caught the attention of Spanish critics. To this day, Kieślowski remains the Polish director best-known to the Spanish - as was made clear in 2016, by the numerous events and screenings marking the $20^{\text {th }}$ anniversary of his death. There can be no doubt that, in the homeland of Buñuel, no other Polish director evokes as much enthusiasm. Considering the Spanish reaction to the maker of the Three Colours, this article focuses on the distribution of Kieślowski's works in Spain, as well as the director's presence at the Spanish Festivals. Further subjects of analysis are reviews by Spanish critics and the state of research into Kieslowski's creative output in the Spanish language, as well as the release of his films on DVD and Blu-Ray. The above focus on festivals, the attitudes of critics, and the popularity among the Spanish viewing public is supplemented by a study of the impact of Kieślowski's output on the work of Spanish directors, as well as efforts to discern the direct influence of the former's films in offering the latter inspiration.
\end{abstract}

KeYwords: Krzysztof Kieślowski, Spain, San Sebastián, Valladolid, festival, DVD, Blu-ray, Three Colours, Decalogue

The films of Krzysztof Kieślowski arrived in Spain comparatively late, and when they did, this was mainly due to the Film Festivals at San Sebastian and Valladolid, as well as with facilitation by independent producers. In 1988, A Short Film About Love (Krótki film o miłości, 1988), under the Spanish title No Amarás, was presented in the San Sebastian Festival's main competition, winning the Jury's Special Prize and the FIPRESCI Prize. While the still-fresh triumph of A Short Film About Killing (Krótki film o zabijaniu, 1987, prem. 1988) at Cannes must have echoed throughout the Spanish press, it was only the second Decalogue (Dekalog, 1988) film and its release in cinemas that first revealed the cinematographic world of the Polish director to the Spanish public and film critics.

The author of one contemporary review, Eduardo Rodríguez Merchán, admitted outright that: "Krzysztof Kieślowski is almost unknown to the Spanish public, even though he is currently one of the most prominent Polish Directors".[1] The same reviewer, writing in 2015,

[1] E. Rodríguez Merchán, “No amarás”, „Diario 16” 1989 (October 8). 
refers back to this comment, admitting that: "today I have come back to the review I wrote then (of A Short Film About Love) and almost cannot believe the ignorance of the critics then - myself included - when it came to the Polish Director".[2]

Admittedly, this is indeed hard to imagine today, especially considering that Kieślowski is among the Polish Directors best known to the average Spaniard. The numerous events and film screenings which took place in Spain in 2016 to commemorate the $20^{\text {th }}$ anniversary of the artist's death serve as the most incontrovertible proof that, as a Polish filmmaker, Kieślowski's fame and recognition in the homeland of Buñuel remains unparalleled.

The first Spaniards to beat a path to the aforementioned popularity were the brothers José María and Miguel Morales. Their adventure with Kieślowski began with their purchasing the Spanish rights to Decalogue. José María recalls meeting the director for the first time in San Sebastián in 1988; but it was only when he arrived in Warsaw for the premiere of $A$ Short Film About Love that the two were able to get to know one another better. This meeting bore fruit in a longer-term friendship, and in the subsequent release of the Three Colours (Trzy kolory) in Spain, which inaugurated the activities of the company Wanda Films[3] that the two brothers founded. Blue (Niebieski, 1993) was watched by 600,000 viewers in Spain, Red (Czerwony, 1994) by 300,000, and White (Biaty, 1993, prem. 1994) by 150,000. Blue received the Best Foreign Film Award of the Spanish Film Academy[4], and was presented in the official section outside the competition at the Valladolid Film Festival. Apart from San Sebastián, where Kieślowski was a guest twice, the Valladolid Festival contributed most to his popularity on the Iberian Peninsula.[5]

The latter Spanish Film Festival, inaugurated in 1956 and initially known as "International Religious Film Week"[6], was already appreciating Polish filmmakers by the 1960 - beginning with Jerzy

[2] E. Rodríguez Merchán, “No amarás y No matarás. La poesía de la prosa", [in:] La doble vida de Krzysztof Kieślowski, ed. J. Bardzinska, San Sebastián 2015, p. 129.

[3] The production and distribution firm Wanda Films was founded by José María Morales in 1992, who was joined shortly thereafter by Miguel Morales. In 1997, the two brothers collaborated with Ricardo Évole in setting up Wanda Vision. Over the last 25 years, Wanda Films and Wanda Vision have brought more than 200 films to Spanishcinemas, as well as producing in excess of 60 films. In the process, they have become syonymous with good Latin American and European cinema.

[4] The Spanish Award in the form of a statuette of Goya - known as the Goya Award - was conferred upon Kieślowski at the Berlin Festival, where White - the second of the Three Colours - was given a screening.
[5] As Miguel Morales conceded in an interview for the "El Norte de Castilla" daily: "The screening of Blue in Valladolid, and the presence there of Kieślowski himself, helped a great deal with subsequent distribution nationwide" (F. Lara, "Krzysztof Kieslowski. El azar y la necesidad”, [in:] Tres colores, Blu-ray edition, Wanda Films, Cameo, Spain 2016, p. 8).

[6] The story of the Valladolid Festival goes back to 1956, when it was inaugurated as the Semana Internacional de Cine Religioso. This title was expanded in 1960 to include "humanist values". However, since 1973, the event has been run as Semana Internacional de Cine de Valladolid. Alongside the Festival in San Sebastián, this is among the oldest and most prestigious events of its kind in Spain. 
Kawalerowicz, the first Polish Director included in the official section of the Festival in 1964[7], followed by Andrzej Wajda and Andrzej Zanussi, who over the years became regular fixtures of the Festival[8], and later Witold Leszczyński, Jerzy Skolimowski and Władysław Ślesicki, who also received Awards. This exceptional relationship with Polish directors was the result of the keen eye Festival organisers had for arthouse cinema and socially engaged films touching upon transcendental ethical questions - a sensitivity shared by filmmakers of the Polish School, or the Cinema of Moral Anxiety.

It therefore comes as no surprise that it was here that the pictures of Kieślowski were particularly prized, praised and watched with special emotion. Nevertheless, it was not until the 1990 s that the director would come to Valladolid. In 1992, at the screening of films from the Łódź Film School, work by Andrzej Wajda, Krzysztof Zanussi, Roman Polański, Lech Majewski and Zbigniew Rybczyński was augmented by two Kieślowski films never before seen in Spain, i.e. The Office (Urzad, 1966)[9] and Concert of Requests (Koncert życzeń, 1967)[10]. One year later, Kieślowski himself was a guest at the Festival, and his film Blue[11] received a non-competition screening. Fernando Lara, director of the Festival between 1984 and 2005, recalled his meeting with the Polish director and confessed: "It was unforgettable - the most fascinating meeting in my 20 years of organising the Festival". [12] Ten years later, during the Polish Year in Spain (El año de Polonia en España), the Festival presented no fewer than 15 Polish films released between 1992 and 2002, including The Double Life of Veronique (La Double vie de Véronique, 1991).

The above screenings were accompanied by an exhibition of photography by Piotr Jaxa, entitled Recordando a Kieślowski (Remembering Kieślowski), and including 31 photographs from the sets of Three Colours. Blue was screened once more at Valladolid in 2016, as part of a series commemorating the $50^{\text {th }}$ anniversary of the Festival, in which 60 full-length Festival-winning films were remembered.

The main effect of a search through Spanish newspapers for articles about and reviews of Kieślowski films were articles on the Spanish premieres of A Short Film About Love (October 6, 1989), The Double Life of Veronique (January 17, 1992), and Three Colours (1993-1994), as well as Decalogue - which was shown on television by TVE in 1991.

[7] The first Polish film officially selected for the Festival was Night Train (Pociag, 1959) by Jerzy Kawalerowicz, which was screened outside the competition in Valladolid in 1964. Four years later in 1968, another film by the same director was screened, i.e. Mother Joan of the Angels (Matka Joanna od aniołów, 1960, prem. 1961). Finally, the official selection in 1984 included the film Austeria (1982, prem. 1983).

[8] In 1968, Zanussi won a Lábaro de Oro for the short Death of a Provincial (Śmierć prowincjała, 1965). In 1970, The Structure of Crystal (Struktura kryształu, 1969) took the City of Valladolid Award, while in 1972 Family Life (Życie rodzinne, 1970, prem. 1971) received the San Gregorio Award. In 1970, Zanussi himself was awarded for his overall achievement. Andrzej Wajda was another strong presence in the 1970 , with 1972 featuring a screening of 8 Wajda films. At the same time Landscape After the Battle was screened in the Festival's Cultural-Information Section.

[9] Spanish title: La ventanilla.

[10] Spanish title: El concierto de los mejores deseos.

[11] Spanish title: Azul.

[12] F. Lara, "El azar y la necesidad", [in:] Krzysztof Kieślowski (book included in the Spanish Blu-Ray edition of the trilogy Three colours by Krzysztof Kieślowski), Cameo 2016, p. 7. 
Interestingly, the frequency with which the director's name is mentioned in the Spanish press does not decrease, but rather increases, with time, especially around the successive anniversaries of his death. In 2006, extra interest was occasioned by the cinematic premiere of $A$ Short Film About Killing, a film which had admittedly been shown previously on television, and at the San Sebastián Festival, but never before reached Spain's big screens. In 2006, both full-length films forming parts of Decalogue, i.e. A Short Film About Killing and A Short Film About Love were released on DVD in Spain, as was The Double Life of Veronique. It is worth mentioning here that this DVD edition also included among its Extra Materials on Disc 2 the documentary films The Factory (Fabryka, 1970), The Hospital (Szpital, 1977), and The Railway Station (Dworzec, 1980).

A decade later, in 2016, commemoration of the $20^{\text {th }}$ anniversary of Kieślowski's death, involving Wanda Vision and Kieślowski’s faithful distributor José Maria Morales, saw the Three Colours trilogy return to cinema screens in 16 cities around Spain, in combination with a release in a new Blu-Ray edition.[13] At the same time, all the leading Spanish papers published reviews of Kieślowski's films written by the country's leading cinema critics. There can be no doubt that their perspective, built up over a period of 20 years, points to the special place the Polish director occupies in their esteem, and in the pantheon of European and World cinema.

For its part, the Spanish daily "ABC" published an article by Oti Rodríguez Marchante, which speaks of a film career crowned by "great work, a trilogy incomparable with any other", in which Kieślowski reached a summit with $A$ Short Film About Love and A Short Film About Killing, climbed the Everest of filmmaking with The Double Life of Veronique, and conquered the Himalayas with his Decalogue. To Rodriguez's mind, the Three Colours are the final act of this great work, equal to that of Bergman or Tarkowski in incisiveness, depth, poetry and reflection. He admits "it is rare for cinema to reach such heights of precision and elegance in the expression of emotion, and its translation into details, signs, images, colours and music".[14]

For his part, Luis Martínez, writing for "El Mundo" expresses his delight, opining that Kieślowski, using his camerawork, is able to make the viewer "hear light". "It is in this play of surprise and fascination that the entire effort of the filmmaker lies, as he builds metaphysical worlds out of everyday, banal objects", the Spanish publicist asserts.[15] Aside from the definite respect and thrill indicated by these quoted passages, the opinions of Spanish critics indicate a clearly highlighted need for a return to the cinema of Kieślowski, with its contemporary relevance and European dimension.

[13] The aforementioned Blu-Ray edition was accompanied by a booklet with texts on Kieślowski's life and work: "El azar y la necesidad" ("Chance and Necessity") by Fernando Lara, and "Krzysztof Kieślowski, lo importante es caminar" ("Krzysztof Kieślowski, and the Importance of Going”) by Joanna Bardzińska.
[14] O. Rodríguez Marchante, "Tres colores, cinco estrellas”, „ABC” 2016, March 11, p. 61.

[15] L. Martínez, "El sonido de la luz", "El Mundo" 2016, March 11, p. 47. 
During a "20 Years Without Kieślowski” Conference convened at the Casa del Lector in Madrid[16], the aforementioned director of the Valladolid Festival, critic and journalist Fernando Lara, began his speech by saying:

We are all in agreement that Krzysztof Kieślowski is an indispensable point of reference for contemporary European cinema, and in particular for what is known as 'Auteur Cinema'. Twenty years on from the death of Kieślowski, his films and personality remain pertinent, indeed to such an extent that his films continue to be screened, his work continues to be analysed, and his films resonate with the cinematic traditions of successive generations. Perhaps younger viewers, now responding to other impulses and passions, are less conscious of his influence. But that is why it is all the more important to introduce our younger viewers to his work through cinematic screenings, and the issuing of new DVD and Blu-Ray editions of his films. [17]

Carlos Boyero highlights the same tendency in the title of his article for "El País", which reads "Cinema from Another Era? No, cinema which is always relevant". One of Spain's most esteemed film critics explains beautifully in his text here, why a new generation needs to be introduced to Kieślowski's films. In the Three Colours, he perceives a chance to inspire their enthusiasm for Auteur Cinema, and reflective film-making. Carlos writes:

How to encourage new generations of viewers, who have increasingly become greedy consumers of pictures not requiring an attention span of more than 5 minutes; to encourage action-addicted Youtubers that it is worth spending a few euros for the contemplation offered by a small-scale film screening, in which an artist using skilled camerawork slowly, unhurriedly describes a spiritual state and conducts, in his own way, a conversation about characters with uncertain pasts or futures, people on the edge of pain with hearts breaking, about feelings and experiences that require time, aesthetics and discipline to be properly depicted on-screen, and about the secrets which are revealed in human nature when trapped in a situation with no way out? How to sell young people on a world in which a look, a tiny gesture, a word or shade, or the tempo of a scene replace rhetoric and black-and-white moral divisions? How? By releasing once more the Trilogy with which Kieślowski said his great farewell to cinema.[18]

Kieślowski's films thus serve, not only as a synonym for $\mathrm{Au}$ teur Cinema, but also as an opportunity for his forgotten values to be resuscitated, and for the sensitivity of new generations to be shaped. "I know that Kieślowski 'sucks one in', as soon as one gets to know him, sees one of his films" [19], concludes Fernando Lara; meanwhile Carlos Boyero believes that Kieślowski's return to the big screen may evoke

[16] The debate held at the Casa del Lector on March 12th included Polish guests (Witold and Danuta Stok, Joanna Bardzińska), as well as Fernando Lara - the Spanish journalist and critic and long-time director of the Valladolid Film Festival.

[17] F. Lara, Krzysztof Kieślowski o el impulso ético speech pronounced at the Conference 20 años sin
Kieślowski, Casa del Lector, Madrid 2016, March 12. [18] C. Boyero, “¿De otra época? No, cine de siempre", „El País” 2016, March 11, p. 31.

[19] F. Lara, Krzysztof Kieślowski o el impulso ético, op. cit. 
fascination among younger viewers, and show them, as Karmitz puts it: "that it is possible to have a European Cinema which, without negating its own history or collective memory, endeavours at the same time to be a cinema of universal values".[20] Interestingly, Lara, who not only headed up the Festival at Valladolid, but also had personal interactions with Kieślowski, admits years later that what impressed him most about the Polish director was his willingness to speak about Europe. Recalling contemplations about the present and future of the Old Continent, the foundations and contradictions behind the current geopolitical and cultural situation of the people of Europe, which Kieślowski made the main theme of a memorable meeting at Valladolid in 1993, he compares the director of the Three Colours to the Italian writer and essayist Claudio Magris, who was equally taken up by the fate and history of our continent.

In the previously cited article published in "El Mundo" in 2016, Luis Martínez also draws attention to the same aspect of Kieślowski's cinematic accomplishments, deeming the trilogy "a fascinating, hopeless, and visionary voyage into the depths of the European continent", which is, moreover, shockingly up-to-date considering that, as he says, "from the perspective of today, against the background of the recent migration crisis, few films appear equally incisive and relevant".[21]

When discussing the reception of Kieślowski's films in Spain, it is worth mentioning the religious interpretation his work has received. Fernando Lara speaks directly of an "attempt to claim" Kieślowski's films by Catholic circles, as was also the case with the films of Dreyer, Bergman and Tarkowski, for whom spirituality was just as important as it was for the director of Decalogue.

It is true that the first book published about Kieślowski in Spain was released in 1998 by the Jesuit publishing house Ediciones Mensajero [Serafino Murri, Krzysztof Kieślowski]. His films were also on the receiving end of in-depth comment on the pages of the Catalonian Catholic periodical "Questions de Vida Cristiana". The reviews which accompanied television broadcasts of Decalogue reveal that it was deemed by the publication "an interesting and personal work, in which Kieślowski, by telling stories often drawing directly on the Ten Commandments, attempts to capture the Polish concept of religion - and with it his own". [22]

Not infrequently, screenings were also organised by Church institutions, such as the Centro Cultural del Arzobispado, and the Centro Internacional para el Estudio del Oriente Cristiano (ICSCO), which organised a Decalogue screening in 2010, with individual episodes given titles corresponding to each of the Ten Commandments.[23] Nonetheless, while these concrete measures certainly did contribute to

[20] S. Zawiśliński, Kieślowski. Pamięć. Życie po życiu, Warszawa 2007, p. 79.

[21] L. Martínez, "El sonido de la luz", op. cit., p. 47. [22] A. Martínez Torres, “TVE-2 comienza esta noche a emitir Decálogo, del polaco Krzysztof Kieslowski”, „El País” 1991, January 10 [https://elpais.com/ diario/1991/o1/10/radiotv/663462002_850215.html]. [23] In place of Decalogue 1, Decalogue 2, and so on, the programme featured the titles: Soy Dios, tu Señor ('Thou Shalt have No Other Gods Before Me'), No invocarás el nombre de Dios en vano ('Thou Shalt Not Take the Name of the Lord in Vain'), etc. 
the popularisation of Kieślowski's work in Spain, as seen from today's perspective, they did not in any way bias or stigmatise its reception or interpretation. Discussing spirituality in Kieślowski's films, Spanish critics generally admit "that it is concerned, not with religious spirituality, even though it does on occasion share with it certain features, but with a lay spirituality, or rather one with a moral aspect, resulting always from the inner need of the author"[24]; "The Lay Chaplain of the Humanist Religion" - as the Polish director was described at the time of a 2005 retrospective of his films, which inaugurated the Segovia Review of European Cinema (Muestra de Cine Europeo de Segovia). The presence of Kieślowski at the genesis of one of the most prominent Festivals of European Film in Spain speaks for itself.

The Spanish bibliography on the Polish director is relatively small, however. Besides the aforementioned book by Serafino Murri (which augments a short presentation of Kieślowski's complete filmography with a very interesting interview with the author from 1995), only one other monograph existed until recently: Julio Rodríguez Chico's work on the Three Colours entitled Azul, Blanco, Rojo. Kieślowski en busca de la libertad y el amor (Blue, White, Red. Kieślowski in Search of Freedom and Love, 2004). In September 2015, a collective work entitled La doble vida de Krzysztof Kieślowski, and published by Donostia Kultura and the Basque Film Archive, appeared on the Spanish market. This monograph combines in one work the opinions of Polish and Spanish critics, presenting Kieślowski's entire filmography from these two perspectives (amongst the Polish authors one finds Stanisław Zawiślinski, Tadeusz Lubelski, Tadeusz Sobolewski, Mikołaj Jazdon and Sebastian Smoliński; and amongst the Spanish - Eduardo Rodríguez Merchán, Federico García Serrano, Julio Rodríguez Chico, Antonio Santamarina and César Ballester). The book also contains Spanish translations of Kieślowski's own texts, and a Prologue by Agnieszka Holland.[25]

The aforementioned publication appeared as part of a series of events organised by the Basque Film Archive and Donostia Kultura in cooperation with the Polish Institute in Madrid, to commemorate the $20^{\text {th }}$ anniversary of Kieślowski's death. The book gained presentation during the $63^{\text {rd }}$ San Sebastián Film Festival, accompanying an exhibition devoted to Kieślowski's life and work. Soon afterwards, a retrospective of his films was organised in the Basque Film Archive's Tabakalera Center. In 2016 Kieślowski's films were commemorated by Film Archives in many other Spanish cities, while, as was mentioned above, commercial cinemas organised screenings of the Three Colours trilogy - which was also released on Blu-Ray at the same time. Spanish television (TVE2) also reminded the public of Kieślowski's work in 2016,

[24] F. Lara, Krzysztof Kieślowski o el impulso ético, op. cit.

[25] At this time, preparatory work is being done on a Spanish translation of Kieślowski's autobiography, as well as a Spanish-language version of his biography.
Both projects are being pursued by the author of this article, under an artistic grant for the promotion of culture awarded by Poland's Ministry of Culture and National Heritage. 
releasing a documentary entitled Kieślowski, documentalista del alma (Kieślowski - the chronicler of the soul). This was produced by Virginia García and Javier Sales, as part of the cinema-review programme Días de cine.

The documentary uses unique material from the Spanish television archives, including interviews conducted with Kieślowski by Spanish journalists, which serve to complete a fascinating portrait of Decalogue's author.[26] Two further events connected to the Polish director were organised in cooperation with the AVA Arts Foundation in Madrid in March, namely a cycle of his documentary films screened by the Cineteca; and the aforementioned " 20 Years Without Kieślowski" Conference in the Casa del Lector, as accompanied by the screening of the documentary Krzysztof Kieślowski: I'm So-So, by Krzysztof Wierzbicki (1995).

The warm welcome granted to all these events and initiatives connected with the 2016 anniversary allows one to appreciate the extent of the Polish director's popularity in Spain, and proves that interest in his work and his person are rather increasing than diminishing. A good measure of this interest may be afforded by the public's reaction to last year's Spanish release of the newly digitally-remastered version of the most prominent works of Polish cinematography, entitled Martin Scorsese presenta las obras maestras del cine polaco.[27]

Amongst all the works presented there, it was Kieślowski's films which met with the greatest interest: screened to full cinemas every time, they delighted, moved, shocked, and provoked discussion. During the inauguration of the 2016 review of documentaries at the Cineteca, the cinema was also at capacity, and after the screening, a meeting with one of the director's former co-workers, Witold Stok, was held. Even the guest of honour was shocked by the high attendance and never-ending questions, with many young people present, including a group of young film-makers curious to learn their art at the Master's workshop.

The presence of the latter inclines one to think about the influence of Kieślowski's films on the work of Spanish directors, as well as the elements inspired by his films. Amongst the best-known Spanish film-makers, whose work resembles that of Kieślowski most closely, is Julio Medem - a self-taught director, trained surgeon, and passionate amateur psychiatrist, who made his debut in 1992 with the film Cows

[26] The report referred to can be accessed at: http:// www.rtve.es/alacarta/videos/dias-de-cine/dias-cinekrzysztof-kieslowski/3528632/

[27] The cycle, going by the name of Martin Scorsese Presents: the Masterpieces of Polish Cinema, was first put on in the USA, UK, Canada and Australia. However, 2017 saw five Spanish cities (Madrid, Barcelona, Cordoba, Valencia and Oviedo) play host to screenings of 9 titles from the series, i.e. Ashes and
Diamonds (Popiót i diament, 1958) and The Promised Land (Ziemia obiecana, 1974, prem. 1975) from A. Wajda, K. Zanussi's Constans (1980), J. Kawalerowicz's Austeria (1982, prem. 1983) and Night Train (Pociag, 1959), The Hourglass Sanatorium (Sanatorium pod Klepsydra, 1973) by W.J. Has, Walkover (Walkower, 1965) by J. Skolimowski, and Blind Chance (Przypadek, 1981, prem. 1987) and A Short Film About Killing by K. Kieślowski. 
(Vacas), and became known in Poland many years later, for the film Lovers of the Arctic Circle (Los amantes del círculo polar, 1998).

Of the entire body of work of this Spanish director, it was this film, released in Poland by Gutek Film, which owes most to the author of Decalogue. The story of Ana and Otto, who fall in love as children, grow up under one roof when their parents decide to start a relationship, and after many years find one another once more at the very edge of the North Pole, is a metaphysical tale of love, blind chance and destiny, which with its subject matter, sensitive tone and mysterious narrative, carries the intertwined fates of its protagonists, and visually references Blind Chance, The Double Life of Veronique and the Three Colours.

The Spanish director himself concedes that the filming technique, with camerawork by Gonzalo F. Berridi, was inspired by Blue. Amongst the common features of Medem and Kieślowski, apart from the aforementioned question of destiny and chance, is the great significance each attaches to film editing and montage, the use of music, cooperation with actors, and the professionalism and surgical precision of the work which goes into each film project, from writing the screenplay to filming the scenes. It is not without reason that on Julio Medem's official website, in the "Miscellaneous" section, we find Krzysztof Kieślowski amongst the bibliographies of three artists who have proven especially inspiring (alongside Iván Zulueta and Víctor Erice).

The creator of Decalogue also plays a significant role in the career of certain filmmakers of the younger generation, including Judith Colell[28] (b. 1968) and Diego Fandos[29] (b. 1971). They themselves do not deny it, relating their fascination with Kieślowski thus:

[Judith Colell:] I first became acquainted with Kieślowski's work through the superb A Short Film About Love, a part of the Decalogue film series. I was then 19 or 20 years old, and dreamed of making films of my own. I was delighted by his method of storytelling, so personal, so one-of-a-kind; the way he worked with actors, the way he worked with lighting on set, how he used music, to lend a rhythm to his work. I became an enthusiastic admirer of his films, I was truly fascinated. As soon as I began to make my own short films, Kieślowski became an important source of inspiration for me. I think that this is easily discernible in my work, although these were, of course, only the amateurish first steps of a young director.

Having made my first full-length film, Nosotras, which by my reckoning was rather too conventional, I decided that the next one would be more courageous, and more personal. And this is how 53 días de invierno came about. In order to discover one's own path, it is important to locate outside reference points; and Kieślowski was, for me, one of the most important. And for numerous reasons. Due to the way in which he treated his characters, the way

[28] The director known for films like Nosotras (2001), 53 días de invierno (2007) and Elisa K (2010), as well as TV productions Positius (2008), Fragments (2003), Radiacions (2012), Lúltim ball de Carmen Amaya (2014). She heads the Departament of Film at Ramon Llull University in Barcelona.
[29] A Spanish writer and director who has made both documentaries and shorts (Under Presssure, Kalimera, Aurora). Cosmos (2008) represented his full-length debut. 
he made use of silence, the incredibly subtle acting he directed, the symbolic use of colour, closely reflective of the characters' personality. These were my guidelines when working on 53 días de invierno, and this is what I've been aiming at ever since I started making films. And though I do have other role models in my career, for me as a director Kieślowski remains the key one.[30]

(Diego Fandos): I first began to write stories when I was a child, but it never occurred to me to become a film director... that is, until I saw the film Blue. It was then that I thought: and why not? Perhaps because Blue seems ostensibly like a very simple film, but is also incredibly deep on an emotional level. Perhaps this is why it motivated me to make the attempt. Only later did I understand that this superficial simplicity was in fact devised very meticulously, and that matching the director of Blue in terms of skill was just out of the question...

In fact, Kieślowski probably had too great an influence on me. I feel that I had to step out from his shadow, to "kill the father", at least as far as style goes, in order to be able to spread my wings. Now, I find him in the films of directors such as Nuri Bilge Ceylan, or Andrei Zviaguintsev, in whose work his influence is, in my view, strikingly present. The Double Life of Veronique was for me a point of reference when making my film Cosmos. Decalogue and all the subsequent films made by Kieślowski seem to me unreachably glorious, but my perennial favourite remains Blue.[31]

Neither Judith Colell nor Diego Fandos are as well known to the Polish public as Julio Medem, though their confessions and their films serve to complete the picture of references to Kieślowski's work in Spanish cinema - because in their cases these references are directly evident. In 53 Days of Winter [32] (53 días de invierno) the starting point of the story is the meeting of three people at a bus stop: a teacher, who has quit her job; a security guard struggling to support his family; and a student involved in a complicated relationship with an older man. These people do not know one another, and will probably never meet again; but for the duration of the film we will follow their struggles with reality, and the decisions which influence their lives.

This construction of a story comprising several strands, the inter-twining of the fates of many different characters, who all meet in one superficially insignificant moment, is without a doubt Kieślowski's playbook, which he realised in all his work from Decalogue through to the Three Colours. If we add to that knowledge that the strangers in 53 Days of Winter will be connected by the tragedy of an abandoned dog (almost as in Red, where Valentine meets the Judge while rescuing a stray dog); that the student is a talented cellist (the theme of a musical career common to The Double Life of Veronique and Blue), while the mother of the student is suffering from depression after her departed husband (with a sluggishness and withdrawn nature that thus recalls Julia in Blue), we may understand the degree to which Kieślowski's pic-

[30] J. Colell - interview by J. Bardzińska (January 23, 2018).

[31] D. Fandos - interview by J. Bardzińska (January $1,2018)$.
[32] While no Judith Colell or Diego Fandosa films have ever been distributed in Poland, 53 Days of Winter could be watched at the $9^{\text {th }}$ Spanish Cinema Week run in 2006. 
tures have shaped the work of the Spanish director. In her subsequent film, Elisa $K$, the story of a young girl who one day recalls spontaneously a traumatic memory from childhood, Colell experiments with visual and narrative form (black and white shots, the presence of a narrator, two timeframes), and there are relatively fewer Kieślowski-style touches. Nevertheless, as she herself admits, "he remains a key influence".

A similar process - from the emulation of the style of the master filmmaker, to its internalisation and liberation - occurs in the work of Diego Fandos, whose first film pays homage to the author of The Double Life of Veronique, even resorting to a somewhat naïve aping of Kieślowski's style, only to attempt to build a style of his own in subsequent productions.

It is Kieślowski, who alongside Wajda and Polański, is the Polish director mentioned most frequently by the Spanish. And it is undoubtedly he who, even today, draws the largest crowds. In the context of Polish-Spanish references and influence on film, it is also he who has had the greatest influence in the last 20 years. And there could have been even more of these references: as Kieślowski's long-time friend and film distributor José María Morales says, just before the former's death the two were in talks about co-production and filming in Spain of Purgatory as a new trilogy, on which the director had worked with Krzysztof Piesiewicz. Today, we can only speculate what this film of Kieślowski's would have looked like, had it indeed been shot in Spain...

The article is based on the research by the author within the Scholarship Program of Polish Ministry of Culture and National Heritage.

Boyero C., “¿De otra época? No, cine de siempre”, “El País” 2016, March 11

Colell J. - interview by J. Bardzińska, January 23, 2018

Fandos D. - interview by J. Bardzińska, January 1, 2018

La doble vida de Krzysztof Kieślowski, ed. J. Bardzińska J., San Sebastian 2015

Lara F., Krzysztof Kieślowski o el impulso ético, speech pronounced at the Conference 20 años sin Kieślowski, Casa del Lector, Madrid, March 12, 2016

Lara F., El azar y la necesidad in; Krzysztof Kieślowski (book included in the Spanish Blu-Ray edition of the trilogy Three colours by Krzysztof Kieślowski), Cameo 2016

Martínez L., "El sonido de la luz", "El Mundo” 2016, March 11

Martínez Torres A., "TVE-2 comienza esta noche a emitir Decálogo, del polaco Krzysztof Kieslowski”, "El País” 1991, January 10

[https://elpais.com/diario/1991/01/10/radiotv/663462002_850215.html]

Murri S., Krzysztof Kieślowski, Bilbao 1998

Rodríguez Chico J., Azul, Blanco, Rojo. Kieslowski en busca de la libertad y el amor, Madrid 2004

Rodríguez Marchante O., “Tres colores, cinco estrellas”, “ABC” 2016, March 11

Rodríguez Merchán E., "No amarás”, “Diario 16” 1989, October 8

Zawiśliński S., Kieślowski. Pamięć. Życie po życiu, Warszawa 2007 